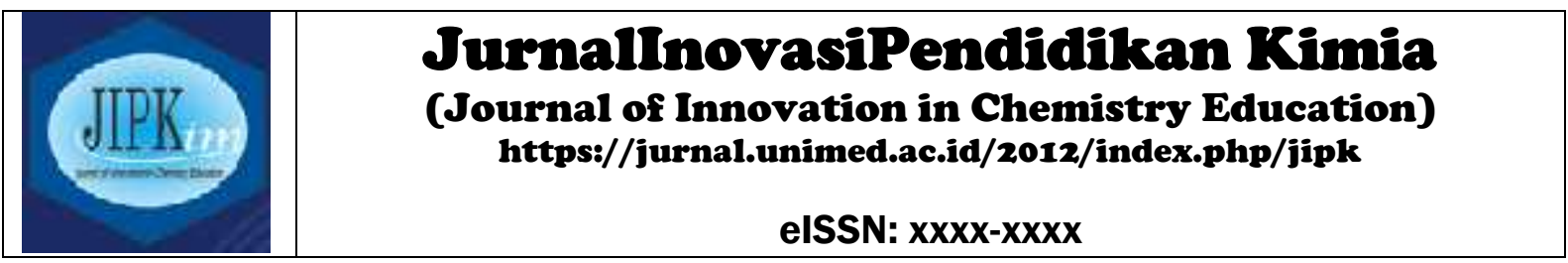

\title{
Pengaruh PBL Terhadap Keterampilan Generik Sains Siswa Pada Materi Larutan Elektrolit dan Non Elektrolit
}

\author{
Dwi Retno Sari ${ }^{\mathrm{a}, *}$, dan Ratu Evina Dibyantini ${ }^{\mathrm{a}}$ \\ ${ }^{a}$ Jurusan Pendidikan Kimia, Universitas Negeri Medan, Medan \\ *Alamat Korespondensi:email@institusi.ac.id
}

\begin{abstract}
:
This study aims to determine the effect of problem-based learning model (PBL) on students' generic science skills in electrolyte and non-electrolyte solution material. This research is an experimental research. The population in this study were all class X students of SMA Negeri 1 Lubuk Pakam. Sampling was done randomly by taking 2 classes, namely one experimental class (PBL model) and one control class (DI model). The instruments used in the form of objective tests in the form of multiple choices amounted to 20 questions and essay questions to measure students' critical thinking skills as many as 5 questions. Homogeneous and normal data were analyzed by paired sample t-test and N-gain normalized using SPSS Version 20. The results showed that there was an influence of PBL learning models on students' generic science skills in electrolyte and nonelectrolyte solution materials. The generic skills of direct observation science are the most developed generic science skills while the lowest generic science skills are symbolic language.
\end{abstract}

Keywords: Generic science skills, PBL, DI, critical thinking skills.

\section{PENDAHULUAN}

Kimia merupakan salah satu mata pelajaran wajib yang harus dikuasai siswa jurusan IPA karena mata pelajaran ini merupakan mata pelajaran yang masuk dalam Ujian Nasional. Namun pada saat ini tingkat penguasaan materi siswa terhadap pelajaran kimia masih sangat rendah. Konsep yang kompleks dan abstrak dalam ilmu kimia menjadikan siswa beranggapan bahwa pelajaran kimia merupakan pelajaran yang sulit (Marsita, 2010). Berdasarkan pengamatan peneliti bidang kimia yang mengajar menggunakan metode pembelajaran ceramah sehingga proses pembelajaran cenderung teacher centered, Sedangkan berdasarkan tujuan pendidikan dalam Undang-Undang tentang sistem Pendidikan Nasional No.20 Tahun 2003, pendidikan ditujukan untuk mengembangkan kemampuan peserta didik agar memiliki keterampilan yang diperlukan dalam

$\begin{aligned} & \text { menjalani kehidupan di lingkungan } \\ & \text { masyarakat. }\end{aligned}$

Untuk itu, diperlukan penalaran anak didik yang diasah sedemikian rupa melalui model pembelajaran yang inovatif untuk menumbuhkan kemampuan berpikir kritis siswa dan meningkatkan keterampilan generik sains siswa. kemampuan berpikir kritis melatih peserta didik untuk membuat keputusan dari berbagai sudut pandang secara cermat, teliti, dan logis. Masalah yang dihadapi guru dalam proses mendidik adalah belum menemukan cara yang efektif untuk meningkatkan keterampilan generik sains siswa. Di mana hal ini sejalan dengan hasil penelitian Anwar (2014) bahwa rendahnya keterampilan generik sains siswa dikarenakan kurang sesuainya model pembelajaran dengan materi yang diajarkan. Untuk meningkatkan keterampilan generik sains siswa dan hasil belajar siswa, diperlukan model pembelajaran yang tepat, karena keterampilan generik sains bertumpu pada pemahaman konsep dan pemecahan 
masalah (Kusdiwelirawan, 2015), maka diperlukan model pembelajaran yang mengajak siswa untuk memecahkan masalah dalam kehidupan nyata.

Nina Fitriana, dkk (2017) menunjukkan bahwa ada pengaruh model pembelajaran problem based learning terhadap hasil belajar kimia materi hidrolisis dan keterampilan generik sains siswa, dimana besarnya pengaruh masing masing adalah $19,88 \%$ dan 43,2\%. Penerapan model Pembelajaran Berbasis Masalah mampu meningkatkan keterampilan generik sains mahasiswa dengan indikator pengamatan langsung, pengamatan tak langsung, hukum sebab akibat, inferensi logika dan kerangka logika taat azas. Hayatus Zakiyah (2014) menunjukkan peningkatan keterampilan generik sains tertinggi pada indikator pengamatan langsung dengan $\mathrm{N}$-Gain $50,11 \%$ kategori sedang, dan terendah pada indikator inferensi logika dengan N-Gain $17,26 \%$ kategori rendah, dimana model pembelajaran berbasis masalah dapat meningkatkan keaktifan mahasiswa dalam mengikuti proses pembelajaran.

Berdasarkn uraian diatas maka peneliti tertarik melakukan penelitian untuk melihat bagaimana keterampilan generik siswa dengan menggunakan model Problem Based Learning (PBL) dan Direct Insruction (DI) pada pokok bahasan Larutan Elektrolit dan Non Elektrolit.

\section{METODE}

Penelitian ini dilaksanakan di SMA Negeri 1 Lubuk Pakam Kabupaten Deli Serdang. Sampel dipilih secara acak dari enam kelas menjadi terpilih dua kelas. Satu kelas sebagai kelas eksperimen diberi perlakuan model $P B L$ dan kelas kontrol pembelajaran $D I$. Jumlah siswa yang dilibatkan dalam penelitian ini adalah 60 orang siswa, yang terdiri dari 30 orang siswa dari kelas X IPA 4 dan 30 orang siswa dari kelas X IPA 6.

Dalam penelitian ini, digunakan rancangan faktorial $2 \times 2$ menggunakan SPSS versi 20. Ada dua faktor yang diteliti, yaitu faktor model pembelajaran (A) dan faktor kemampuan berpikir kritis (B). Faktor A terdiri dari dua taraf yaitu, model Pembelajaran Berbasis Masalah $(P B L)$ dan model pembelajaran Direct Instruction (DI). Faktor B juga terdiri dari 2 taraf yaitu, kemampuan berpikir kritis tingkat tinggi dan kemampuan berpikir kritis tingkat rendah.

Pengumpulan data dilakukan dengan pemberian intrumen tes berupa soal pilihan ganda untuk mengetahui keterampilan generik sains siswa dan soal essay untuk mengetahui kemampuan berpikir kritis siswa.

\section{HASIL DAN PEMBAHASAN}

Data yang diperoleh dalam penelitian ini adalah nilai keterampilan generik sains siswa pada materi Larutan elektrolit dan non elektrolit. Data-data diambil dari kelompok eksperimen yaitu kelas yang diberi perlakuan model PBL dan kelas kontrol yaitu kelas yang diberi perlakuan model DI.

\section{Pengaruh Model Pembelajaran dan Keterampilan generik}

Data keterampilan generik sains berdasarkan model PBL dlihat berdasarkan nilai pretest, postest dan N-Gain. Deskripsi data berikut disajikan dalam tabel berikut ini

Tabel 1. Deskripsi Nilai Pretest, Postest, dan N-Gain Siswa Berdasarkan Model Pembelajaran

\begin{tabular}{|c|c|c|c|}
\hline \multicolumn{4}{|c|}{ Problem Based Learning } \\
\hline Model & $\begin{array}{c}\text { Rerata } \\
\text { Pre-test }\end{array}$ & $\begin{array}{c}\text { Rerata } \\
\text { Post-test }\end{array}$ & N-Gain \\
\hline $\begin{array}{c}\text { Pembelajaran } \\
\text { Berbasis Masalah }\end{array}$ & 39,67 & 84 & 0,736 \\
\hline
\end{tabular}

Dari data tabel diatas diketahui nilai pretest sebesar 39,67 sedangkan postest sebesar 84. N-gain sebesar 0,736 hal ini menunjukkan bahwa terjadi peningkatan dari rerata pretest menuju postest sehingga dapat disimpulkan penggunaan model $P B L$ dapat meningkatkan keterampilan generik sains siswa sebesar 73,6 \%.

\section{Kemampuan Berpikir Kritis Siswa}

Dalam penelitian ini dilakukan pengukuran kemampuan berpikir kritis 
siswa dengan memberikan instrumen tes berupa soal essay dengan tingkat kemampuan berpikir kritis siswa tingkat tinggi yang diberikan pada kelas eksperimen dan kelas kontrol. Tujuan dari pemberian tes kemampuan berpikir kritis ini adalah untuk menggolongkan siswa yang diteliti kedalam 2 golongan yaitu siswa dengan kemampuan berpikir kritis tinggi dan siswa dengan kemampuan berpikir kritis rendah.

Tabel 2. Nilai Kemampuan Berpikir Kritis Siswa Kelas Eksperimen dan Kelas Kontrol

\begin{tabular}{lcccc}
\hline $\begin{array}{c}\text { Kelom } \\
\text { pok }\end{array}$ & $\begin{array}{c}\text { Jumlah } \\
\text { Data }\end{array}$ & $\begin{array}{c}\text { Nilai } \\
\text { Tertinggi }\end{array}$ & $\begin{array}{c}\text { Nilai } \\
\text { Terendah }\end{array}$ & $\begin{array}{c}\text { Rata- } \\
\text { Rata }\end{array}$ \\
\hline $\begin{array}{l}\text { Eksperi } \\
\text { men }\end{array}$ & 30 & 95 & 60 & 78,629 \\
Kontrol & 30 & 90 & 55 & 72,228 \\
\hline
\end{tabular}

Setelah itu, data kemampuan berpikir kritis siswa dikategorikan dalam 2 kategori yaitu, pertama kemampuan berpikir kritis tinggi bagi siswa yang memiliki nilai kemampuan berpikir kritis $\geq$ rata-rata nilai kemampuan berpikir kritis seluruh siswa dan yang kedua, kategori kemampuan berpikir kritis rendah bagi siswa yang memiliki nilai kemampuan berpikir kritis $\leq$ rata-rata nilai kemampuan berpikir kritis seluruh siswa.

Tabel 3. Frekuensi Penggolongan Kemampuan Berpikir Kritis Siswa Kelas Eksperimen dan Kelas Kontrol

\begin{tabular}{ccc}
\hline \multirow{2}{*}{$\begin{array}{c}\text { Kemampuan } \\
\text { Berpikir Kritis }\end{array}$} & $\begin{array}{c}\text { Kelas } \\
\text { Eksperimen }\end{array}$ & $\begin{array}{c}\text { Kelas } \\
\text { Kontrol }\end{array}$ \\
\cline { 2 - 3 } & \multicolumn{2}{c}{ Frekuensi } \\
\hline Tinggi & 20 & 14 \\
Rendah & 10 & 16 \\
Jumlah & 30 & 30 \\
\hline
\end{tabular}

\section{Data Keterampilan Generik Sains Siswa (KGS)}

Data KGS siswa dalam penelitian ini diperoleh dari nilai post-test. Diperoleh data untuk siswa yang diberi pengajaran dengan model PBL Learning dan memiliki kemampuan berpikir kritis tinggi diperoleh rataan KGS ( 85,75 \pm 5,684 ) dan untuk kelas yang diberi pengajaran dengan model pengajaran Problem Based Learning dengan kemampuan berpikir kritis tingkat rendah diperoleh rataan KGS $(80,50 \pm 3,689)$. Untuk kelas yang diberi pengajaran dengan model $D I$ dengan kemampuan berpikir kritis tingkat tinggi diperoleh rataan KGS ( 80,36 \pm 4,584 ) dan untuk kelas yang diberi pengajaran dengan model DI dengan kemampuan berpikir kritis siswa tingkat rendah diperoleh rataan $\mathrm{KGS}(80,31 \pm$ $3,860)$. Data rataan keterampilan generik sains siswa yang diperoleh siswa untuk setiap kombinasi perlakuan disajikan pada tabel dibawah ini :

Tabel 4. Rataan Keterampilan Generik Sains Siswa yang Diberi Kombinasi Pengajaran Model Pembelajaran dan Kemampuan Berpikir Kritis

\begin{tabular}{ccc}
\hline Kemampuan & \multicolumn{2}{c}{ Model Pembelajaran ( A ) } \\
\cline { 2 - 3 } Berpikir & Model PBL & Model DI $\left(\mathrm{A}_{2}\right)$ \\
Kritis (B) & $\left(\mathrm{A}_{1}\right)$ & \\
\hline Tinggi $\left(\mathrm{B}_{1}\right)$ & $(85,75 \pm 5,684)$ & $(80,50 \pm 3,689)$ \\
Rendah $\left(\mathrm{B}_{2}\right)$ & $(80,35 \pm 3,689)$ & $(80,31 \pm 3,860)$ \\
\hline
\end{tabular}

Dari tabel perhitungan berdasarkan data hasil tes untuk kedua kelas sampel yang diperoleh nilai postest kelas eksperimen di gambarkan dalam grafik sebagai berikut :

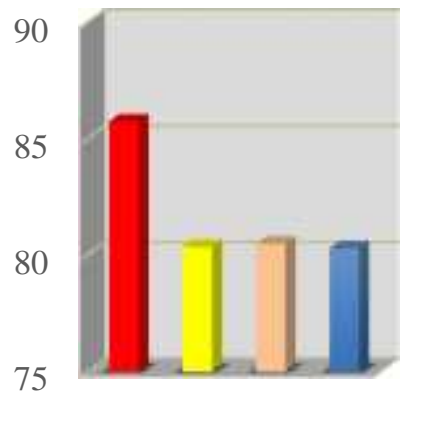

- PBL KBK
Tinggi
PBL KBK
Rendah
PBL DI Tinggi
PBL DI
Rendah

Gambar 1.Kombinasi Model Pembelajaran dengan Kemampuan Berpikir Kritis

Dari data diatas dapat disimpulkan model $P B L$ memberikan pengaruh dalam peningkatan keterampilan generik siswa di kelas eksperimen dan lebih baik pada siswa yang mempunyai keterampilan berpikir kritis tinggi jika dibandingkan dengan kelas yang menerapkan pembelajaran dengan model $D I$.

\section{Hasil Keterampilan Generik Sains Siswa}

\subsection{Peningkatan Keterampilan Generik Sains}

Pada penelitian ini, keterampilan generik sains yang dikembangkan diantaranya pengamatan langsung, bahasa 
simbolik dan konsistensi logis. Keterampilan generik tersebut disebar dalam bentuk instrumen tes yang diberikan pada kelas eksperimen pada tabel 5 berikut.

Tabel 5. Nilai N-Gain tiap Indikator Keterampilan Generik

\begin{tabular}{clccc}
\hline No & Indikator & Pretest & Postest & $\begin{array}{c}\text { N- } \\
\text { Gain }\end{array}$ \\
\hline 1 & $\begin{array}{l}\text { Pengamatan } \\
\text { Langsung } \\
2\end{array}$ & 17,875 & 35,25 & 0,774 \\
& $\begin{array}{l}\text { Bahasa } \\
\text { Simbolik }\end{array}$ & 9,875 & 20 & 0,651 \\
& $\begin{array}{l}\text { Konsistensi } \\
\text { Logis }\end{array}$ & 11 & 27,75 & 0,681 \\
\hline
\end{tabular}

Dapat disimpulkan bahwa nilai $\mathrm{N}$-gain tertinggi sebesar 0,774 pada indikator keterampilan generik pengamatan langsung sedangkan $\mathrm{N}$-gain terendah sebesar 0,651 pada indikator bahasa simbolik. Berdasarkan nilai N-gain tersebut, maka dapat disimpulkan bahwa keterampilan generik sains pengamatan langsung merupakan keterampilan generik sains yang paling terkembangkan sedangkan keterampilan generik sains yang perkembangannya paling rendah adalah bahasa simbolik.

Hal ini didukung dengan beberapa penelitian yang telah dilakukan oleh beberapa peneliti sebelumnya seperti penelitian yang dilakukan oleh Zakiyah (2014), menunjukkan bahwa penerapan model $P B L$ mampu meningkatkan keterampilan generik sains siswa serta dapat meningkatkan keaktifan dalam mengikuti proses pembelajaran. Sejalan dengan penelitian tersebut, penelitian sebelumnya yang dilakukan oleh (Fitriana, 2017), bahwa model $P B L$ berpengaruh terhadap hasil belajar kimia dan keterampilan generik sains siswa. Penerapan model pembelajaran $P B L$ pada materi larutan elektrolit dan non elektrolit dapat mengembangkan ketrampilan generik sains pengamatan langsung dengan maksimal, namun pada indikator bahasa simbolik, perkembangannya kurang maksimal.

\subsection{Hasil Peningkatan Penguasaan Setiap Keterampilan Generik Sains \\ Keterampilan Generik Sains Pengamatan Langsung}

Keterampilan generik sains pengamatan langsung terdapat dalam instrumen tes yang diberikan saat penelitian. Pada penelitian ini, indikator pengamatan langsung tersebar dalam 8 butir soal.Dalam hal ini akan disajikan data analisis nilai pretest, postest, N-Gain dan taraf pencapaian untuk keterampilan generik pengamatan langsung.

Tabel 6.Analisis Skor Pretest, Postest, N-Gain Dan Taraf Pencapaian Untuk Keterampilan Generik Pengamatan Langsung

\begin{tabular}{lcccccc}
\hline $\begin{array}{c}\text { Instru } \\
\text { men } \\
\text { tes }\end{array}$ & $\begin{array}{c}\text { KB } \\
\text { K }\end{array}$ & $\begin{array}{c}\text { Jum } \\
\text { lah } \\
\text { Sis } \\
\text { wa }\end{array}$ & $\begin{array}{c}\text { Rer } \\
\text { ata } \\
\text { Pre } \\
\text { test }\end{array}$ & $\begin{array}{c}\text { Rer } \\
\text { ata } \\
\text { Pos } \\
\text { test }\end{array}$ & $\begin{array}{c}\text { N- } \\
\text { Ga } \\
\text { in }\end{array}$ & $\begin{array}{c}\text { Taraf } \\
\text { Penca } \\
\text { paian }\end{array}$ \\
\hline Soal ( & $\begin{array}{c}\text { Ren } \\
\text { dah }\end{array}$ & 10 & 17,5 & 34,5 & 0,7 & Tinggi \\
2, 6, & dah & & & 43 & \\
8,9, & Tin & 20 & 18,2 & 36 & 0,8 & Tinggi \\
10, & ggi & & 5 & & 05 & \\
11, & & & & & & \\
12, & & & & & & \\
$13)$ & & & & & & \\
\hline
\end{tabular}

Berdasarkan tabel diatas dapat disimpulkan bahwa keterampilan generik pengamatan langsung yang terkembangkan dalam penelitian ini adalah pada KBK Tinggi dengan harga $\mathrm{N}$-Gain sebesar 0,805 dengan taraf pencapaian tinggi.

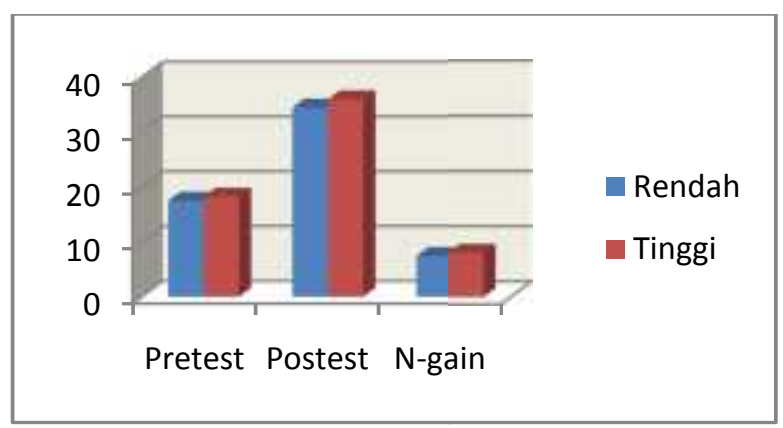

Gambar 2.Keterampilan Generik Sains Pengamatan Langsung pada Kelompok Kemampuan Berpikir Kritis Tingkat Rendah dan Tinggi

\section{Keterampilan Generik Sains Bahasa Simbolik}

Pada penelitian ini indikator bahasa simbolik tersebar dalam 5 butir soal. Dalam hal ini akan disajikan data analisis nilai 
pretest, postest, N-Gain dan taraf pencapaian untuk keterampilan generik bahasa simbolik :

Tabel 7.Analisis Skor Pretest, Postest, N-Gain Dan Taraf Pencapaian Untuk Keterampilan Generik Bahasa Simbolik

\begin{tabular}{ccccccc}
\hline $\begin{array}{c}\text { Instru } \\
\text { men } \\
\text { tes }\end{array}$ & $\begin{array}{c}\text { KB } \\
\text { K }\end{array}$ & $\begin{array}{c}\text { Juml } \\
\text { ah } \\
\text { Siswa }\end{array}$ & $\begin{array}{c}\text { Rer } \\
\text { ata } \\
\text { Pre } \\
\text { test }\end{array}$ & $\begin{array}{c}\text { Rer } \\
\text { ata } \\
\text { Pos } \\
\text { test }\end{array}$ & $\begin{array}{c}\text { N- } \\
\text { Gain }\end{array}$ & $\begin{array}{l}\text { Ta } \\
\text { raf } \\
\text { Pe } \\
\text { nca } \\
\text { pai } \\
\text { an }\end{array}$ \\
\hline $\begin{array}{c}\text { Soal }(3, \\
5,7,\end{array}$ & $\begin{array}{c}\text { Ren } \\
\text { dah }\end{array}$ & 10 & 9 & 19,5 & 0,658 & $\begin{array}{l}\text { Sed } \\
\text { ang }\end{array}$ \\
$14,15)$ & $\begin{array}{c}\text { Tin } \\
\text { ggi }\end{array}$ & 20 & 10,7 & 20,5 & 0,644 & $\begin{array}{l}\text { Sed } \\
\text { ang }\end{array}$ \\
\hline
\end{tabular}

Berdasarkan tabel diatas dapat disimpulkan bahwa keterampilan generik bahasa simbolik yang terkembangkan dengan nilai tertinggi pada kelompok siswa dengan kemampuan berpikir kritis yang rendah dengan harga $\mathrm{N}$-Gain sebesar 0,658 dengan pencapaian kategori sedang.

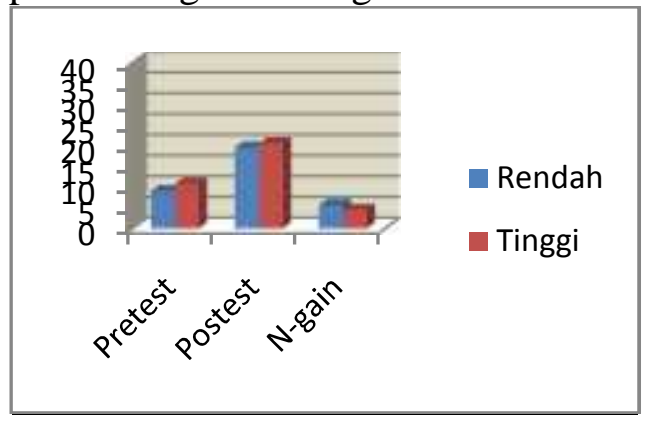

Gambar 3. Keterampilan Generik Sains Bahasa Simbolik pada Kelompok Kemampuan Berpikir Kritis Tingkat Rendah dan Tinggi

\section{Keterampilan Generik Sains Konsistensi Logis}

Pada penelitian ini, indikator konsistensi logis tersebar di 8 butir soal. Dalam hal ini akan disajikan data analisis nilai pretest, postest, N-Gain dan taraf pencapaian untuk keterampilan generik konsistensi logis :

Tabel 7. Analisis Skor Pretest, Postest, N-Gain Dan Taraf Pencapaian Untuk Keterampilan Generik Konsistensi Logis

\begin{tabular}{ccccccc}
\hline $\begin{array}{c}\text { Instr } \\
\text { umen } \\
\text { tes }\end{array}$ & $\begin{array}{c}\text { KB } \\
\text { K }\end{array}$ & $\begin{array}{c}\text { Jum } \\
\text { lah } \\
\text { Sis } \\
\text { wa }\end{array}$ & $\begin{array}{c}\text { Rer } \\
\text { ata } \\
\text { Pre } \\
\text { test }\end{array}$ & $\begin{array}{c}\text { Rer } \\
\text { ata } \\
\text { Pos } \\
\text { test }\end{array}$ & $\begin{array}{c}\text { N- } \\
\text { Ga } \\
\text { in }\end{array}$ & $\begin{array}{c}\text { Taraf } \\
\text { Penca } \\
\text { paian }\end{array}$ \\
\hline $\begin{array}{c}\text { Soal } \\
(1,4,\end{array}$ & $\begin{array}{c}\text { Ren } \\
\text { dah }\end{array}$ & 10 & 9,5 & 12,5 & 0,6 & $\begin{array}{c}\text { Sedan } \\
16,\end{array}$ \\
Tin & 20 & 26 & 29,5 & 0,7 & Tinggi \\
\hline
\end{tabular}

\begin{tabular}{ll}
17, & ggi \\
18, & \\
19, & \\
$20)$ & \\
\hline
\end{tabular}

Berdasarkan tabel diatas dapat disimpulkan bahwa keterampilan generik konsistensi logis yang terkembangkan dengan nilain $\mathrm{N}$-gain tertinggi adalah kelompok siswa dengan kemampuan berpikir kritis tinggi dengan kategori tinggi dan sedang.

Gambar 4. Keterampilan Generik Sains Konsistensi Logis pada Kelompok Kemampuan Berpikir Kritis Tingkat Rendah dan Tinggi

KESIMPULAN

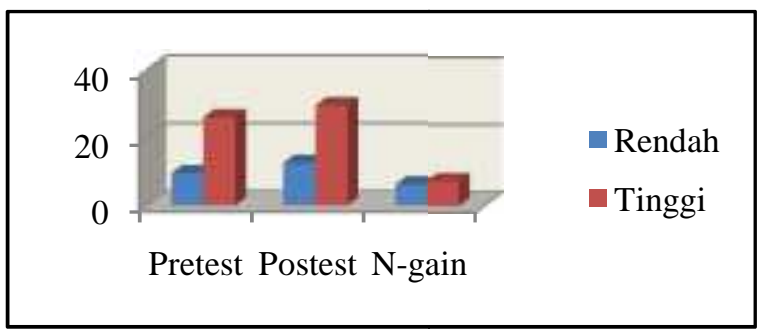

Berdasarkan pada permasalahan penelitian, hasil penelitian serta pembahasan sebagaimana telah dikemukakan di atas dapat disimpulkan bahwa ada pengaruh model $P B L$ terhadap keterampilan generik sains siswa. Nilai $\mathrm{N}$-gain tertinggi sebesar 0,774 pada dicapai indikator keterampilan generik pengamatan langsung sedangkan $\mathrm{N}$-gain terendah 0,651 pada indikator bahasa simbolik. Berdasarkan nilai N-gain tersebut menunjukkan bahwa keterampilan generik sains pengamatan langsung merupakan keterampilan generik sains yang paling terkembangkan sedangkan keterampilan generik sains yang perkembangannya paling rendah adalah bahasa simbolik.

\section{DAFTAR PUSTAKA}

Anwar, M. (2014). The Effect Of ActiveCooperative Learning On Science Generic Skills Of Students In Chemical Kinetics Course For Prospectives Teachers, Journal of Education And Practice, 5(31):149-154.

Fitriana, N. dkk. (2017). Pengaruh Model Problem Based Learning Terhadap Hasil Belajar Kimia Hidrolisis Dan 
Keterampilan Generik Sains, Journal Chemistry In Education, 6(2):55-59.

Kusdiwelirawan, A., dkk. (2015).

Perbandingan Peningkatan Keterampilan Generik Sains antara Model Inquiry Based Learning dengan Model Problem Based Learning, Jurnal Fisika dan Pendidikan Fisika, 1(2):19-23.

Marsita, R.A., dkk. (2010). Analisis Kesulitan Belajar Kimia Siswa SMA Dalam Memahami Larutan Penyangga Dengan Menggunakan Two-Tier Multiple Choice Diagnostic Instrument, Jurnal Inovasi Pendidikan Kimia, 4(1)

Zakiyah, H., dkk. (2014). Implementasi Model Pembelajaran Berbasis Masalah Pada Materi Titrasi Asam Basa Untuk Meningkatkan Keterampilan Generik Sains Mahasiswa Program Studi Pendidikan Kimia, Lantanida Journal, 1 (1):107-122 . 